\title{
Microstructures and Mechanical Properties of Precipitation-Hardenable Magnesium-Silver- Calcium Alloy Sheets
}

\author{
Mingzhe Bian *, Xinsheng Huang and Yasumasa Chino \\ Multi-Material Research Institute, National Institute of Advanced Industrial Science and Technology (AIST), \\ Nagoya, Aichi 463-8560, Japan; huang-xs@aist.go.jp (X.H.); y-chino@aist.go.jp (Y.C.) \\ * Correspondence: mingzhe.bian@aist.go.jp
}

Received: 17 November 2020; Accepted: 2 December 2020; Published: 4 December 2020

check for updates

\begin{abstract}
Precipitation hardening provides one of the most common strengthening mechanisms for magnesium $(\mathrm{Mg}$ ) alloys. Here, we report a new precipitation-hardenable $\mathrm{Mg}$ sheet alloy based on the magnesium-silver-calcium system. In a solution treated condition (T4), the strength of $\mathrm{Mg}-\mathrm{xAg}-0.1 \mathrm{Ca}$ alloys is enhanced with increasing the Ag content from $1.5 \mathrm{wt} . \%$ to $12 \mathrm{wt} . \%$. The $\mathrm{Mg}-12 \mathrm{Ag}-0.1 \mathrm{Ca}$ (wt.\%) alloy sheet shows moderate tensile yield strengths of $193 \mathrm{MPa}, 130 \mathrm{MPa}, 117 \mathrm{MPa}$ along the rolling direction (RD), $45^{\circ}$ and transverse direction (TD) in the T4-treated condition. Subsequent artificial aging at $170^{\circ} \mathrm{C}$ for $336 \mathrm{~h}$ (T6) increases the tensile yield strengths to $236 \mathrm{MPa}, 163 \mathrm{MPa}$ and $143 \mathrm{MPa}$ along the $\mathrm{RD}, 45^{\circ}$ and TD, respectively. This improvement in the tensile yield strength by the T6 treatment can be ascribed to the formation of $\mathrm{AgMg}_{4}$ precipitates lying on the $\{11 \overline{2} 0\}_{a}$ and pyramidal planes. Our finding is expected to stimulate the development of precipitation-hardenable $\mathrm{Mg}-\mathrm{Ag}$-based wrought alloys with high strength.
\end{abstract}

Keywords: magnesium alloys; rolling; strength; segregation; precipitate

\section{Introduction}

The lightest structural metal magnesium $(\mathrm{Mg})$ and its alloys have attracted significant interest in the past two decades due to their potential applications in the automotive sector [1-3]. However, current applications of wrought $\mathrm{Mg}$ alloys as a structural component are very limited, which can be ascribed to their inferior mechanical properties at room temperature (RT) and poor corrosion resistance [4]. Precipitation-hardening, also known as age-hardening, is one of the most effective ways to strengthen $\mathrm{Mg}$ alloys [5,6]. For example, an extraordinary high tensile yield strength of $473 \mathrm{MPa}$ was obtained in a heavy rare-earth (RE) containing Mg-10Gd-5.7Y-1.6Zn-0.7Zr (wt.\%) alloy processed by a conventional extrusion process followed by $20{ }^{\circ} \mathrm{C}$ aging for $64 \mathrm{~h}$ [7]. A RE-free $\mathrm{Mg}-6.2 \mathrm{Zn}-0.4 \mathrm{Ag}-0.2 \mathrm{Ca}-0.4 \mathrm{Zr}$ (wt.\%) alloy subjected to twin-roll cast (TRC), hot-rolling and artificial aging at $160^{\circ} \mathrm{C}$ for $24 \mathrm{~h}$ also yielded a high tensile yield strength of $316 \mathrm{MPa}$ with a large fracture elongation of $17 \%$ [8]. Recent studies reported that $\mathrm{Mg}-\mathrm{Al}-\mathrm{Ca}-\mathrm{Mn}(-\mathrm{Zn})$ dilute alloys could reach their peak hardness condition at $200{ }^{\circ} \mathrm{C}$ within $1 \mathrm{~h}$ that is significantly shorter than the time to reach the peak-hardness conditions of concentrated $\mathrm{Mg}-\mathrm{Gd}, \mathrm{Mg}-\mathrm{Zn}$ and $\mathrm{Mg}-\mathrm{Sn}$ based alloys [9-11]. Microstructure characterization by transmission electron microscopy (TEM), in conjunction with atom probe tomography, revealed that mono-atomic layer Guinier-Preston (G.P.) zones lying on the (0002) basal plane are formed in the peak-aged samples, and their dense distribution is responsible for the strength improvement in $\mathrm{Mg}-\mathrm{Al}-\mathrm{Ca}-\mathrm{Mn}(-\mathrm{Zn})$ alloy sheets [12]. A more recent study demonstrated that bake-hardenability is even obtainable after $170{ }^{\circ} \mathrm{C}$ aging for only $20 \mathrm{~min}$ in a TRC $\mathrm{Mg}-1.3 \mathrm{Al}-0.8 \mathrm{Zn}-0.7 \mathrm{Mn}-0.5 \mathrm{Ca}$ (wt.\%) alloy sheet, which opened up a possibility to develop bake-hardenable Mg alloys [13]. Those studies suggest that the development of precipitation-hardenable alloys is a promising approach to strengthen wrought $\mathrm{Mg}$ alloys. 
In a recent study, we found that the co-addition of $\mathrm{Ag}(1.5 \mathrm{wt} . \%)$ and $\mathrm{Ca}(0.1 \mathrm{wt} . \%)$ to pure $\mathrm{Mg}$ could significantly enhance the stretch formability compared to the single addition of Ag or Ca [14]. A subsequent study achieved a high tensile yield strength of $182 \mathrm{MPa}$ along the rolling direction (RD) by increasing the Ag content to $6 \mathrm{wt}$ \%, while keeping a high index Erichsen value of $8.7 \mathrm{~mm}$ [15]. In a more recent study, we found that a compositionally optimized $\mathrm{Mg}-1.5 \mathrm{Ag}-2 \mathrm{Ca}$ (wt.\%) alloy is non-flammable up to $1000{ }^{\circ} \mathrm{C}$ due to the formation of compact and dense $\mathrm{CaO}$ film on the surface. [16]. If precipitation-hardenability can be obtained by artificial aging, the $\mathrm{Mg}-\mathrm{Ag}-\mathrm{Ca}$ system is expected to attract more attention. Based on the binary $\mathrm{Mg}-\mathrm{Ag}$ phase diagram, the maximum solid solubility of $\mathrm{Ag}$ is about $15 \mathrm{wt} \%$ in $\mathrm{Mg}$ at $472{ }^{\circ} \mathrm{C}$, and it decreases to about $0 \mathrm{wt} . \%$ at $200{ }^{\circ} \mathrm{C}$ [17]. As shown in Figure 1 , the equilibrium mole fraction of $\mathrm{AgMg}_{4}$ phase is about 0.19 at $200{ }^{\circ} \mathrm{C}$ for the binary $\mathrm{Mg}-15 \mathrm{Ag}$ (wt.\%) alloy, indicating there is a high possibility to obtain precipitation-hardenability from the $\mathrm{Mg}-\mathrm{Ag}$ system. In fact, the Ag addition was reported to enhance the age-hardening response and thus increase mechanical properties of $\mathrm{Mg}-\mathrm{Nd}$ alloys more than 50 years ago, which has facilitated the development of a commercial casting alloy QE22 (Mg-2.5Ag-2Nd-0.7Zr in wt.\%) [18]. Subsequent studies showed that the $\mathrm{Ag}$ addition is also very effective in improving the age-hardening response of $\mathrm{Mg}-6 \mathrm{Gd}-0.6 \mathrm{Zr}$ and Mg-6Y-1Zn-0.6Zr (all in wt.\%) casting alloys [19,20]. TEM observations revealed that the remarkable improvement in age-hardening could be ascribed to a dense and uniform distribution of nano-scale basal precipitates. On the other hand, adding a trace amount of Ag (0.4 wt.\%) to a binary $\mathrm{Mg}-6.2 \mathrm{Zn}$ alloy was reported to enhance the age hardening response significantly due to a substantial refinement of $\mathrm{MgZn} 2$ precipitates [21]. However, a closer look at those precipitation-hardenable Ag-containing alloys developed until now, we could find that Ag was mainly added to refine the size of precipitates formed in Mg-RE or Mg-Zn based alloys. To the authors' knowledge, there is no prior research on the development of precipitation-hardenable $\mathrm{Mg}-\mathrm{Ag}$ based wrought alloys, which motivated us to explore the feasibility of developing precipitation-hardenable alloy based on the $\mathrm{Mg}-\mathrm{Ag}-\mathrm{Ca}$ system.

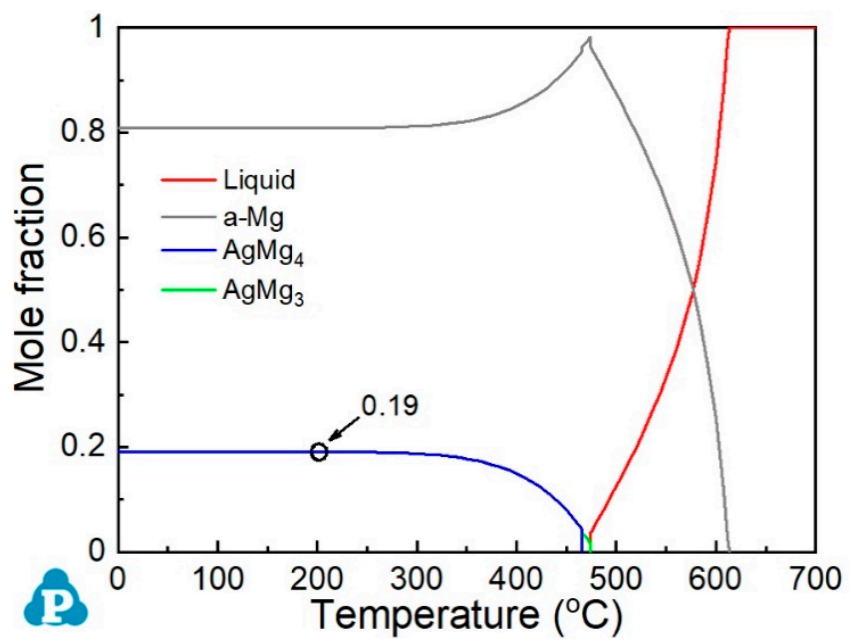

Figure 1. Calculated equilibrium mole fraction of phases as a function of temperature for a binary $\mathrm{Mg}-15 \mathrm{Ag}$ (wt.\%) alloy using the PANDAT software.

In this study, $\mathrm{Mg}-\mathrm{xAg}-0.1 \mathrm{Ca}$ alloys with a composition range from $1.5 \mathrm{wt} \%$ to 12 wt.\% were prepared and their age-hardening response at $170{ }^{\circ} \mathrm{C}$ was evaluated. Tensile properties of $\mathrm{Mg}-1.5 \mathrm{Ag}-0.1 \mathrm{Ca}, \mathrm{Mg}-6 \mathrm{Ag}-0.1 \mathrm{Ca}$ and $\mathrm{Mg}-12 \mathrm{Ag}-0.1 \mathrm{Ca}$ alloy sheets were evaluated at RT, and a systematic microstructure characterization was conducted to clarify the strengthening mechanism in precipitation-hardenable $\mathrm{Mg}-\mathrm{Ag}-\mathrm{Ca}$ alloys. 


\section{Materials and Methods}

$\mathrm{Mg}-\mathrm{xwt} . \% \mathrm{Ag}-0.1 \mathrm{wt} . \% \mathrm{Ca}(\mathrm{x}=1.5,6$ and 12$)$ ingots were produced using pure $\mathrm{Mg}(>99.9 \%)$, pure $\mathrm{Ag}(>99.9 \%)$ and $\mathrm{Mg}-4.92 \mathrm{wt} \% \mathrm{Ca}$ master alloy by an induction furnace (IR) under an Argon (Ar) atmosphere. The chemical composition of alloys used in the present study was analyzed by inductively coupled plasma-optical emission spectroscopy (ICP-OES), and the analyzed results were given in Table 1 . The as-cast alloys were initially extruded as sheets of $5 \mathrm{~mm}$ in thickness at $380^{\circ} \mathrm{C}$. The extrusion ratio and the ram speed were 6 and $5 \mathrm{~mm} / \mathrm{min}$, respectively. The extruded sheets were homogenized at $400{ }^{\circ} \mathrm{C}$ for $18 \mathrm{~h}$ to avoid hot-cracking during rolling, particularly the concentrated $\mathrm{Mg}-12 \mathrm{Ag}-0.1 \mathrm{Ca}$ alloy. The homogenized sheets were rolled from $5 \mathrm{~mm}$ to $1 \mathrm{~mm}$ in thickness with $\sim 21 \%$ thickness reduction per pass by 7 passes. After each pass, the rolled sheets were immediately quenched into cold water. The water quenched sheets were then re-heated to $350^{\circ} \mathrm{C}$ prior to subsequent rolling, and rollers were heated to $90^{\circ} \mathrm{C}$ during rolling. The rolled sheets were solution-treated at $450{ }^{\circ} \mathrm{C}$ for $1 \mathrm{~h}(\mathrm{~T} 4)$ and then quenched into cold water. Some of them were subsequently aged in a silicone oil bath at $170{ }^{\circ} \mathrm{C}$.

Table 1. Chemical composition of Mg-xAg-0.1Ca $(x=1.5,6$ and 12) alloys analyzed by ICP-OES.

\begin{tabular}{ccc}
\hline Alloy & Ag (wt.\%) & Ca (wt.\%) \\
\hline Mg-1.5Ag-0.1Ca & 1.37 & 0.10 \\
Mg-6Ag-0.1Ca & 5.68 & 0.11 \\
$\mathrm{Mg}-12 \mathrm{Ag}-0.1 \mathrm{Ca}$ & 11.0 & 0.10 \\
\hline
\end{tabular}

Dog-bone shaped tensile samples having a parallel length of $12 \mathrm{~mm}$, a width of $4 \mathrm{~mm}$ and a thickness of $1 \mathrm{~mm}$ were machined from the T4-treated sheets along the $\mathrm{RD}\left(0^{\circ}\right), 45^{\circ}$ and $\mathrm{TD}\left(90^{\circ}\right)$. Figure 2 shows a schematic drawing of tensile test samples used in the present study. A screw driven Instron 5565 tensile testing machine was used to evaluate RT tensile properties with a constant testing speed of $2 \mathrm{~mm} / \mathrm{min}$. The age hardening response was evaluated by a HM-200 micro Vickers hardness tester (Mitutoyo Corporation, Kawasaki, Japan) under a load of $200 \mathrm{~g}$ with a holing time of $10 \mathrm{~s}$. Ten points were measured in each condition. The maximum and minimum hardness values were removed, and the remaining 8-point values were averaged. X-ray diffraction (XRD) patterns were obtained from the mid-layers of sheets using Rigaku RINT Ultima III operating at $40 \mathrm{kV}$ and $40 \mathrm{~mA}$ (Rigaku Corporation, Akishima, Japan). Samples for secondary scanning electron microscope (SEM) and electron backscatter diffraction (EBSD) observations were prepared using silicon carbide ( $\mathrm{SiC}$ ) papers, $60 \mathrm{~nm}$ alumina suspension, and Ar ion beam using an ELIONIX EIS-200ER ion beam shower system (ELIONIX Inc., Hachioji, Japan). SEM observation was performed at $15 \mathrm{kV}$ using a JEOL JSM-IT500 equipped with a JEOL EX-74600U4L2Q EDS detector (JEOL Ltd., Akishima, Japan). EBSD measurements were performed at $20 \mathrm{kV}$ using the same SEM equipped with TSL OIM 7.0 data collection software (EDAX Inc., Mahwah, NJ, USA). Samples for TEM observation were mechanically ground to about $150 \mu \mathrm{m}$ in thickness using $\mathrm{SiC}$ papers $(500,1000,2400$, and 4000 grit) and subsequently punched to disks of $3 \mathrm{~mm}$ in diameter. The disks were twin-jet electropolished at about $-50{ }^{\circ} \mathrm{C}$ with a solution of $15.9 \mathrm{~g}$ lithium chloride, $33.6 \mathrm{~g}$ magnesium perchlorate, $1500 \mathrm{~mL}$ methanol and $300 \mathrm{~mL}$ 2-butoxy-ethanol, and finally ion-milled using a Gatan Precision Ion Polishing System (PIPS) (Gatan Inc., Pleasanton, CA, USA). TEM observations were carried out on JEM-2010 and $\mathrm{C}_{\mathrm{s}}$-corrected JEM-ARM200F TEMs operating at $200 \mathrm{kV}$ (JEOL Ltd., Akishima, Japan). The thermodynamic simulation was carried out with the PANDAT software 2020 (CompuTherm LLC, Middleton, WI, USA) [22].

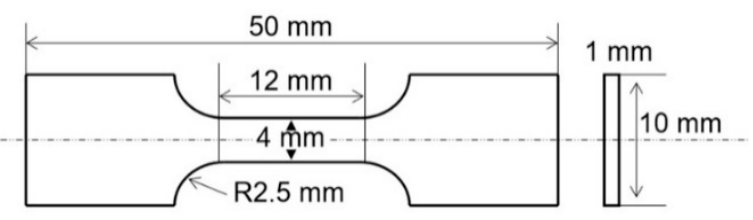

Figure 2. Schematic diagram showing the dimensions of tensile test sample used in this study. 


\section{Results}

Figure 3 shows the age-hardening response of T4-treated $\mathrm{Mg}-\mathrm{xAg}-0.1 \mathrm{Ca}$ alloy sheets $(\mathrm{x}=1.5$, 6 and 12) during isothermal aging at $170{ }^{\circ} \mathrm{C}$. The $1.5 \mathrm{Ag}$ containing alloy sheet shows a low Vickers hardness value of $41.4 \mathrm{HV}$ in the initial condition (T4), and it exhibits a negligible age-hardening. Increasing the Ag content not only leads to a higher hardness value in the T4-treated condition but also enhances the age-hardening response during aging. The $6 \mathrm{Ag}$ containing alloy sheet and the $12 \mathrm{Ag}$ containing alloy sheet show hardness values of $51.1 \mathrm{HV}$ and $67.0 \mathrm{HV}$, respectively. After aging for 336 $\mathrm{h}$, the hardness value of the former is increased to $57.4 \mathrm{HV}$, and that of the latter is increased to 80.0 HV. Table 2 summarizes initial hardness, peak-hardness, time to reach peak hardness and hardness increment of $\mathrm{Mg}-\mathrm{xAg}-0.1 \mathrm{Ca}$ alloy sheets.

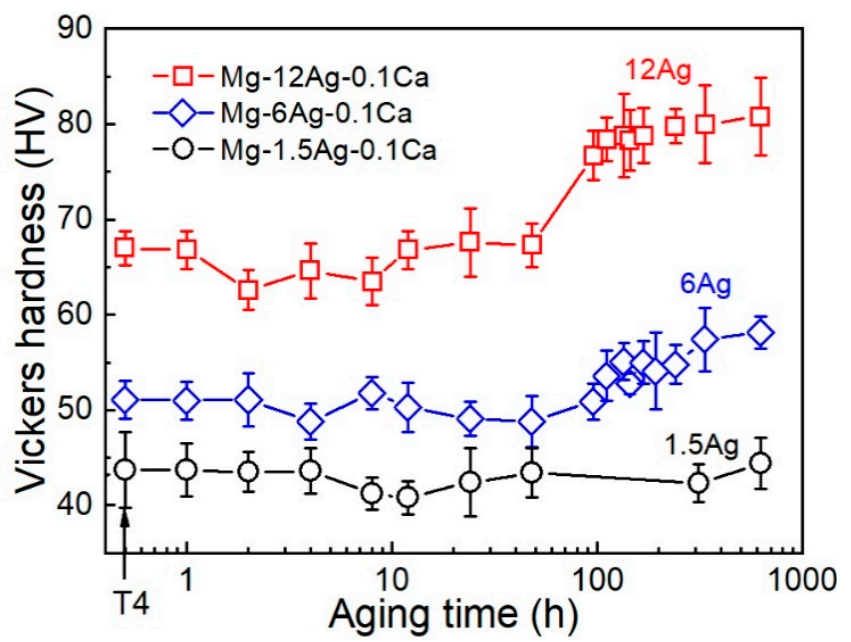

Figure 3. Age-hardening response of $1.5 \mathrm{Ag}, 6 \mathrm{Ag}$ and $12 \mathrm{Ag}$ containing alloy sheets at $170{ }^{\circ} \mathrm{C}$.

Table 2. Initial hardness (T4 condition), peak-hardness, time to reach peak hardness and hardness increment of $1.5 \mathrm{Ag}, 6 \mathrm{Ag}$ and $12 \mathrm{Ag}$ containing alloy sheets.

\begin{tabular}{ccccc}
\hline Alloy & $\begin{array}{c}\text { Initial } \\
\text { Hardness (HV) }\end{array}$ & $\begin{array}{c}\text { Peak Hardness } \\
\text { (HV) }\end{array}$ & $\begin{array}{c}\text { Time to Reach } \\
\text { Peak Hardness (h) }\end{array}$ & $\begin{array}{c}\text { Hardness } \\
\text { Increment (HV) }\end{array}$ \\
\hline $\mathrm{Mg}-1.5 \mathrm{Ag}-0.1 \mathrm{Ca}$ & 41.4 & 43.7 & 0.5 & 2.3 \\
$\mathrm{Mg}-6 \mathrm{Ag}-0.1 \mathrm{Ca}$ & 51.1 & 57.4 & 336 & 6.3 \\
$\mathrm{Mg}-12 \mathrm{Ag}-0.1 \mathrm{Ca}$ & 67.0 & 80.0 & 336 & 13.0 \\
\hline
\end{tabular}

Figure 4 shows tensile properties of the T4- and T6-treated 6Ag and 12Ag containing alloy sheets at RT. For the purpose of comparison, tensile curves obtained from the T4-treated 1.5Ag containing alloy sheet are given as Figure 4a. The tensile yield strength (TYS) of the T4-treated 1.5Ag containing alloy sheet is measured to be only $85 \mathrm{MPa}, 57 \mathrm{MPa}$ and $47 \mathrm{MPa}$ along the RD, $45^{\circ}$ and TD, respectively. Increasing the Ag content to 6 wt.\% increases the TYS to $112 \mathrm{MPa}, 70 \mathrm{MPa}$ and $61 \mathrm{MPa}$ along the RD, $45^{\circ}$ and TD, Figure $4 \mathrm{~b}$. When the Ag content is further increased to $12 \mathrm{wt} . \%$, the TYS is significantly increased to $193 \mathrm{MPa}, 130 \mathrm{MPa}$ and $117 \mathrm{MPa}$, Figure 4c. Subsequent artificial aging (T6) at $170{ }^{\circ} \mathrm{C}$ for $336 \mathrm{~h}$ further increases the TYS of $12 \mathrm{Ag}$ containing alloy sheet to $236 \mathrm{MPa}, 163 \mathrm{MPa}$ and $143 \mathrm{MPa}$ along the $\mathrm{RD}, 45^{\circ}$ and $\mathrm{TD}$, respectively. The uniform elongation (UE) and fracture elongation (FE) of T4-treated $6 \mathrm{Ag}$ and $12 \mathrm{Ag}$ containing alloy sheets are all higher than $20 \%$. However, both UE and FE are substantially reduced to about $10 \%$ after the T6 treatment. The tensile properties of $1.5 \mathrm{Ag}, 6 \mathrm{Ag}$ and 12Ag containing alloy sheets such as TYS, ultimate tensile strength (UTS), UE and FE are summarized in Table 3. 

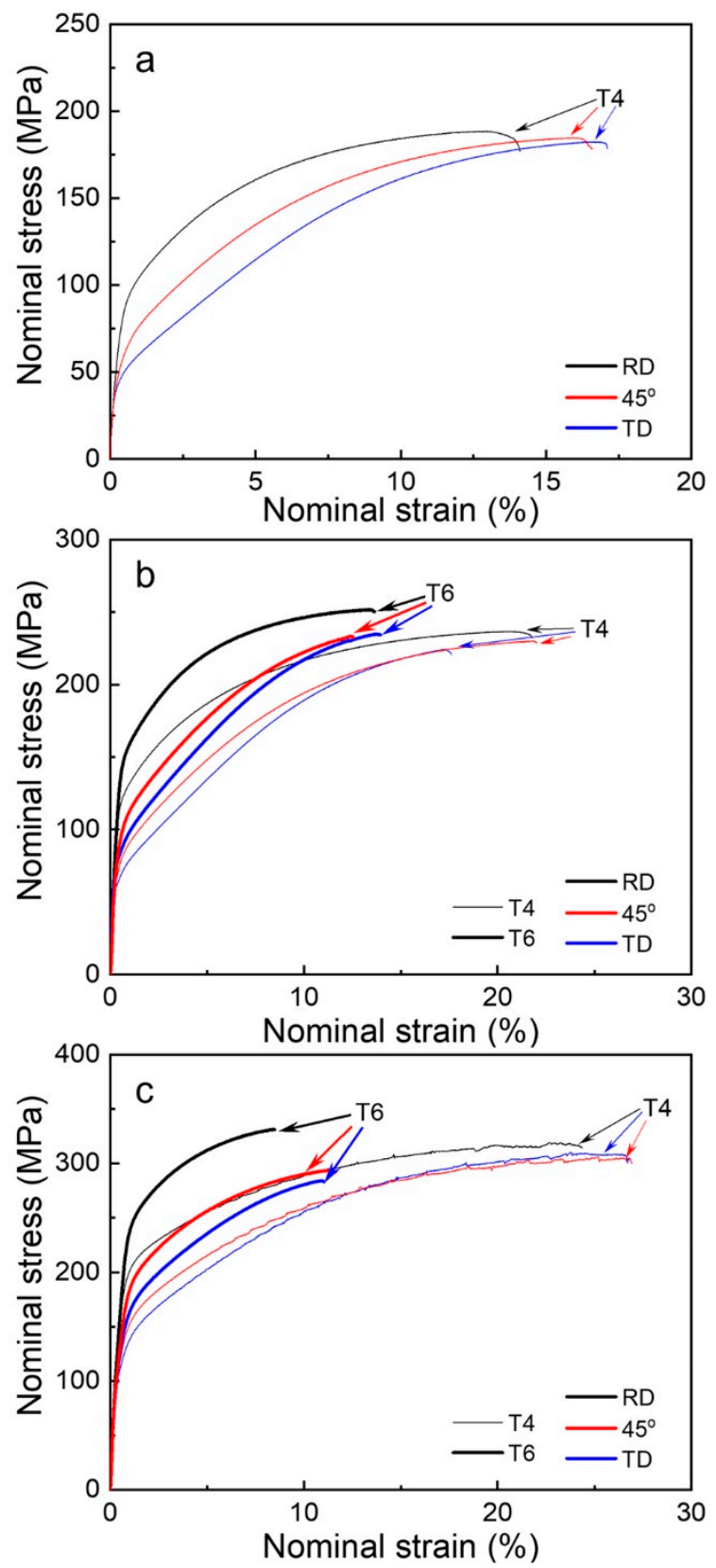

Figure 4. Tensile curves obtained from (a) T4-treated Mg-1.5Ag-0.1Ca alloy sheet, and T4- and T6-treated (b) Mg-6Ag-0.1Ca and (c) Mg-12Ag-0.1Ca alloy sheets along RD, $45^{\circ}$ and TD at RT.

Figure 5 show EBSD inverse pole figure (IPF) maps and corresponding (0002) and (1010) PFs obtained from the T4-treated $1.5 \mathrm{Ag}, 6 \mathrm{Ag}$ and $12 \mathrm{Ag}$ containing alloy sheets. The $1.5 \mathrm{Ag}$ containing alloy sheet shows a coarse-grained microstructure of $\sim 277 \mu \mathrm{m}$, and abnormal grain growth occurs. Increasing the $\mathrm{Ag}$ content to $6 \mathrm{wt} . \%$ refines the microstructure and the average grain size is decreased by about one half $(\sim 124 \mu \mathrm{m})$. In addition, the microstructure homogeneity is enhanced. An increased addition of the Ag content to $12 \mathrm{wt} . \%$ causes further refinement in the microstructure. It is to be noted that a homogeneous microstructure consisting of equiaxed grains with an average grain size of $\sim 74 \mu \mathrm{m}$ is developed in the $12 \mathrm{Ag}$ containing alloy. All alloy sheets show a TD-split texture, in which the (0002) basal poles are tilted toward the TD. 
Table 3. RT tensile properties of $1.5 \mathrm{Ag}, 6 \mathrm{Ag}$ and $12 \mathrm{Ag}$ containing alloy sheets stretched along the RD, $45^{\circ}$ and TD.

\begin{tabular}{|c|c|c|c|c|c|c|}
\hline Alloy & Condition & Direction & TYS (MPa) & UTS (MPa) & UE (\%) & FE $(\%)$ \\
\hline \multirow{3}{*}{$\mathrm{Mg}-1.5 \mathrm{Ag}-0.1 \mathrm{Ca}$} & \multirow{3}{*}{$\mathrm{T} 4$} & RD & 85 & 189 & 12 & 13 \\
\hline & & $45^{\circ}$ & 57 & 185 & 15 & 16 \\
\hline & & TD & 47 & 182 & 16 & 16 \\
\hline \multirow{6}{*}{$\mathrm{Mg}-6 \mathrm{Ag}-0.1 \mathrm{Ca}$} & \multirow{3}{*}{$\mathrm{T} 4$} & $\mathrm{RD}$ & 112 & 237 & 20 & 21 \\
\hline & & $45^{\circ}$ & 70 & 230 & 21 & 22 \\
\hline & & $\mathrm{TD}$ & 61 & 224 & 17 & 17 \\
\hline & \multirow{3}{*}{$\mathrm{T} 6$} & $\mathrm{RD}$ & 149 & 252 & 13 & 13 \\
\hline & & $45^{\circ}$ & 89 & 233 & 12 & 12 \\
\hline & & TD & 81 & 235 & 13 & 14 \\
\hline \multirow{6}{*}{$\mathrm{Mg}-12 \mathrm{Ag}-0.1 \mathrm{Ca}$} & \multirow{3}{*}{$\mathrm{T} 4$} & RD & 193 & 319 & 22 & 24 \\
\hline & & $45^{\circ}$ & 130 & 306 & 24 & 26 \\
\hline & & TD & 117 & 310 & 23 & 26 \\
\hline & \multirow{3}{*}{$\mathrm{T} 6$} & $\mathrm{RD}$ & 236 & 331 & 8 & 8 \\
\hline & & $45^{\circ}$ & 163 & 294 & 11 & 11 \\
\hline & & TD & 143 & 284 & 10 & 10 \\
\hline
\end{tabular}
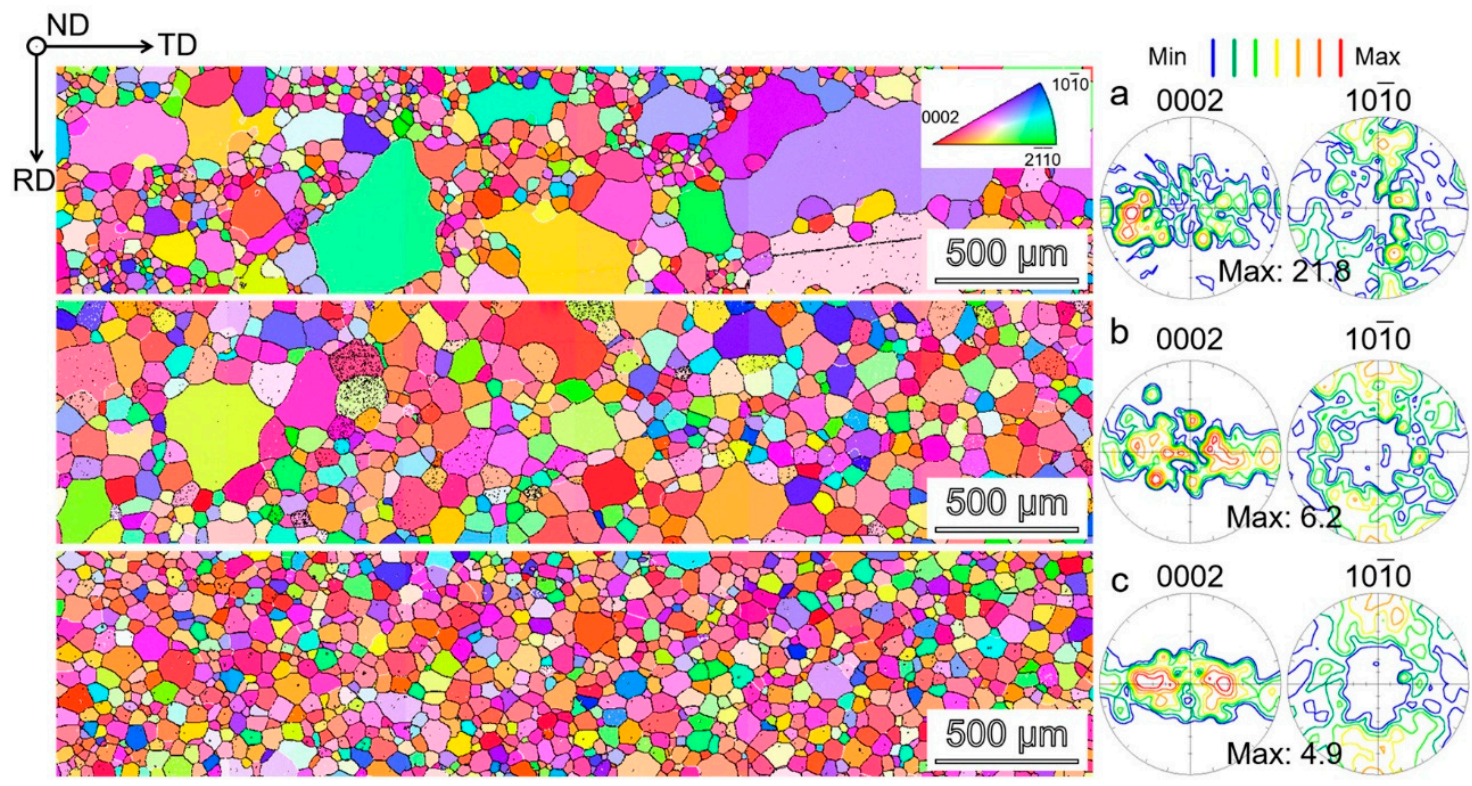

Figure 5. EBSD inverse pole figure (IPF) maps and corresponding (0002) and (1010) PFs showing microstructures and textures of T4-treated (a) $\mathrm{Mg}-1.5 \mathrm{Ag}-0.1 \mathrm{Ca}$, (b) $\mathrm{Mg}-6 \mathrm{Ag}-0.1 \mathrm{Ca}$, and (c) $\mathrm{Mg}-12 \mathrm{Ag}-0.1 \mathrm{Ca}$ alloy sheets.

To understand the reasons why the grain size is decreased with increasing the Ag content, the microstructures of T4-treated samples were observed by SEM. As can be seen from Figure $6 a, b$, the microstructures of the $1.5 \mathrm{Ag}$ and $6 \mathrm{Ag}$ containing alloy sheets consist of only $\alpha-\mathrm{Mg}$, indicating that solute atoms are fully dissolved into the $\mathrm{Mg}$ matrix after annealing at $450{ }^{\circ} \mathrm{C}$ for $1 \mathrm{~h}$. In contrast, the $12 \mathrm{Ag}$ containing alloy sheet contains coarse second phase particles that are located both within the grains and along the grain boundaries, Figure $6 \mathrm{c}$. The backscattered electron (BSE) image and corresponding $\mathrm{Ag}$ and $\mathrm{Ca}$ EDS maps indicate that these particles are mainly enriched with $\mathrm{Ag}$, Figure $6 \mathrm{~d}-\mathrm{f}$. Point analysis on a particle (marked with a triangle in Figure $6 \mathrm{~d}$ shows that an atomic ratio between $\mathrm{Mg}$ and $\mathrm{Ag}$ is close to 4, Figure $6 \mathrm{~g}$. Based on our previous study, these particles are believed to be $\mathrm{AgMg}_{4}$ phase [15]. The microstructure of the T4-treated $\mathrm{Mg}-12 \mathrm{Ag}-0.1 \mathrm{Ca}$ alloy sheet was further observed by TEM. Figure 7a shows the high-angle annular dark-field scanning transmission electron microscopy 
(HAADF-STEM) image, in which the contrast is proportional to the square of the atomic number $[23,24]$. The grain boundary is therefore believed to be enriched with $\mathrm{Ag}(Z=47)$ and or $\mathrm{Ca}(Z=20)(\mathrm{Mg}$, $Z=12$ ) because the grain boundary looks much brighter than adjacent grains. The corresponding Ag and Ca EDS maps reveal that Ag and Ca are co-segregated along the grain boundary, Figure $7 \mathrm{~b}, \mathrm{c}$.
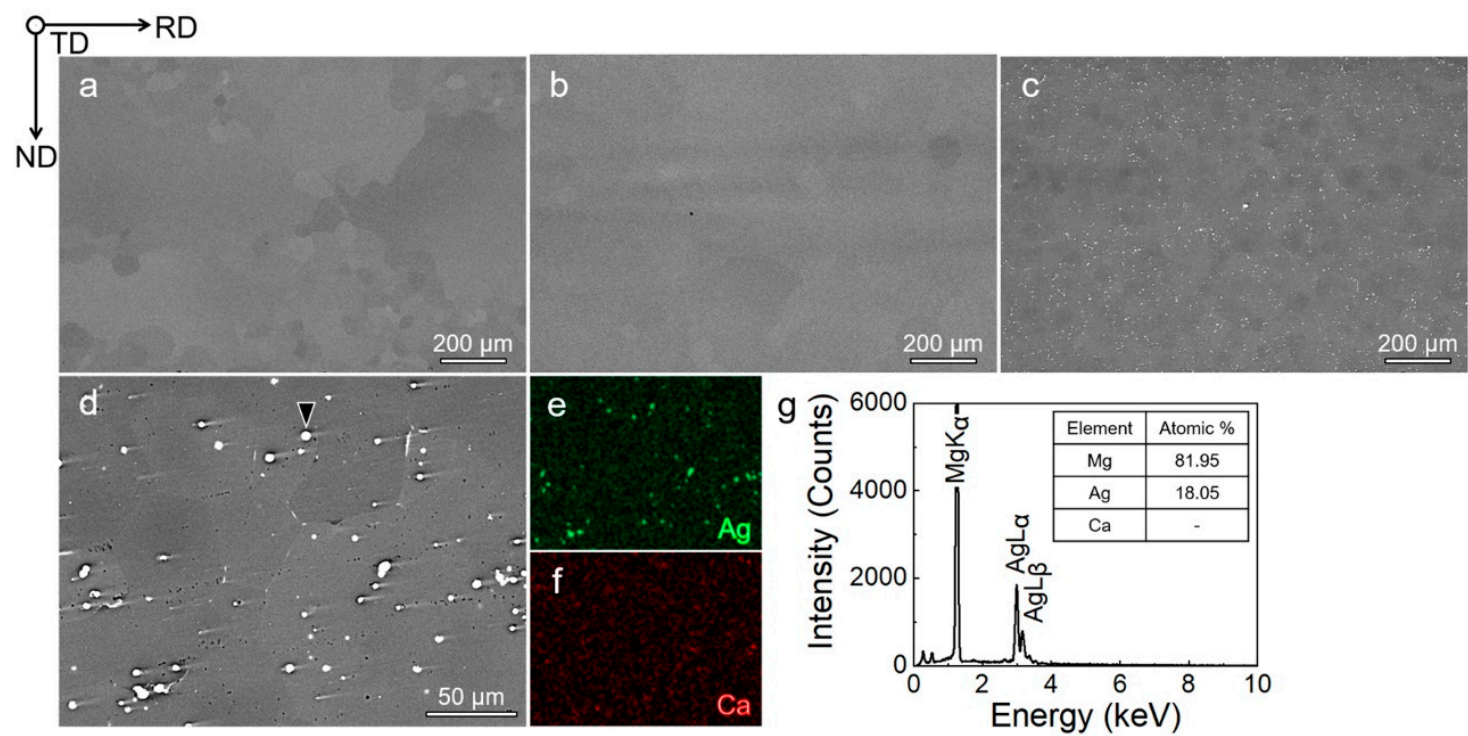

Figure 6. Backscattered electron (BSE) images showing microstructures of T4-treated (a) Mg-1.5Ag$0.1 \mathrm{Ca}$, (b) Mg-6Ag-0.1Ca, and (c) Mg-12Ag-0.1Ca alloy sheets. (d) BSE image, and corresponding (e) Ag and (f) Ca elemental maps obtained from the Mg-12Ag-0.1Ca alloy sheet. (g) EDS spectrum obtained from a second phase particle (marked with a triangle) in (d).
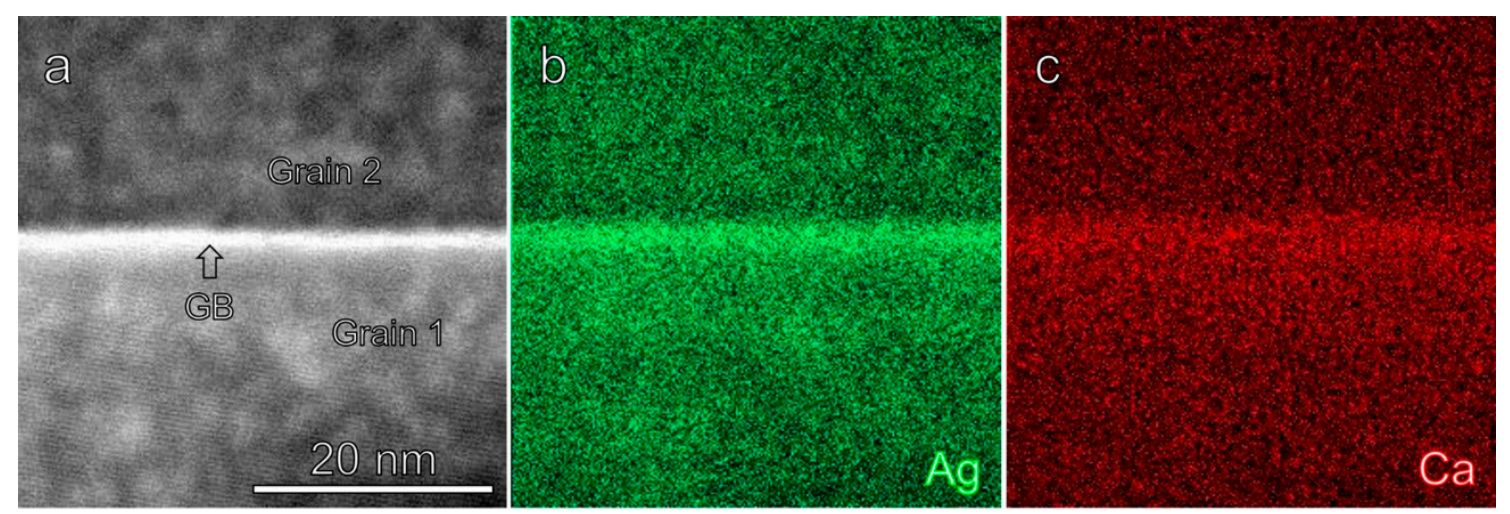

Figure 7. (a) High-angle annular dark-field-STEM image and (b) Ag and (c) Ca elemental maps showing the co-segregation of $\mathrm{Ag}$ and $\mathrm{Ca}$ atoms along a grain boundary of T4-treated $\mathrm{Mg}-12 \mathrm{Ag}-0.1 \mathrm{Ca}$ alloy sheet.

To clarify the reasons for the enhanced TYS after aging, the microstructure of the T6-treated 12Ag containing alloy sheet was observed by TEM. Figure 8a,b show the bright field (BF) TEM images taken with the incident beam along the $[0001]_{a}$ and $[10 \overline{1} 0]_{a}$ zone axes, respectively. The dispersion of precipitates is homogeneous, and the morphologies of the precipitates seem to consist of rod and polygonal shapes. The rod-type precipitates with a length of $0.5-2.5 \mu \mathrm{m}$ are on the $\{11 \overline{2} 0\}_{\mathrm{a}}$ plane and their growing direction is parallel to the $\left\langle 10 \overline{1} 0>_{a}\right.$ or $[0001]_{a}$ directions. It is to be noted that some rod type precipitates lay on the pyramidal plane, as indicated by triangles in Figure $8 \mathrm{~b}$. 

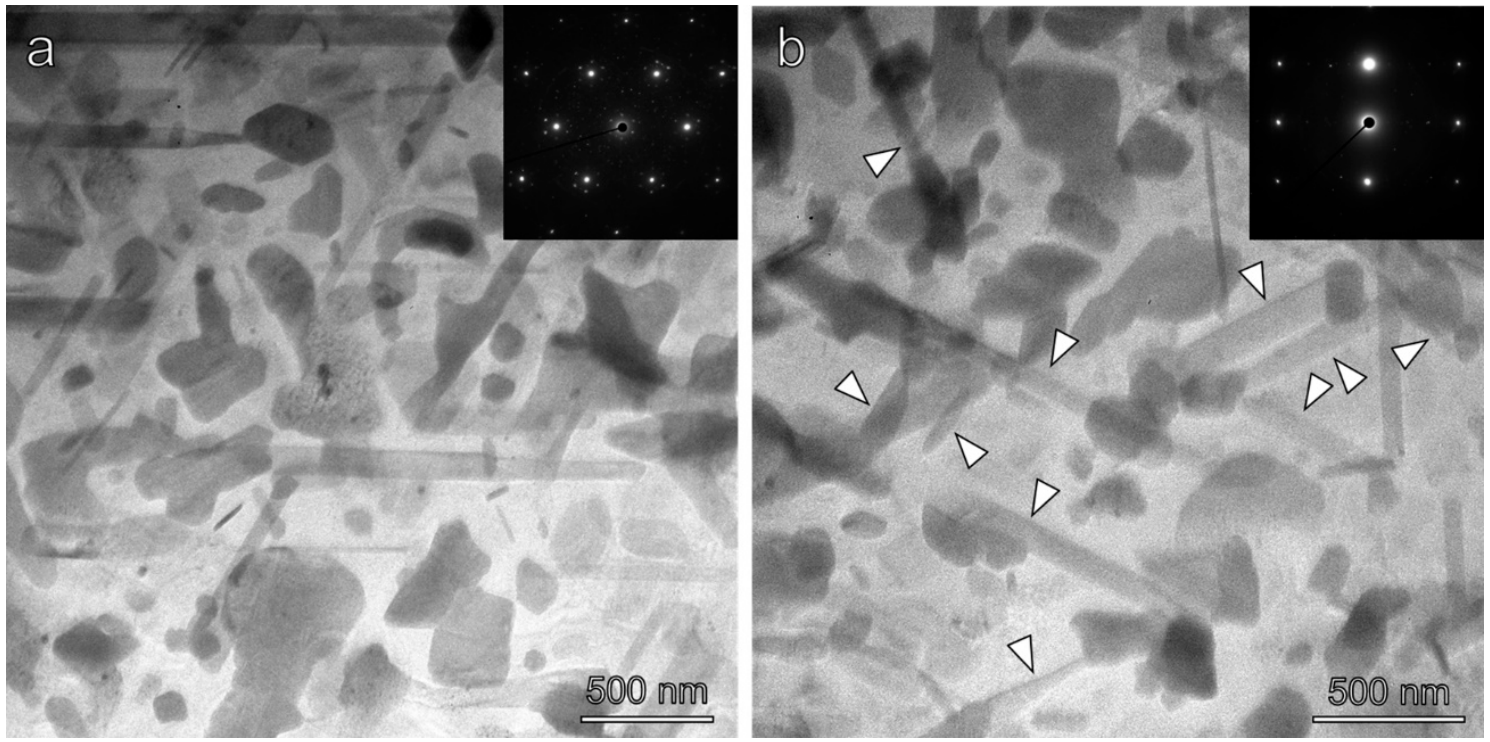

Figure 8. Bright field-TEM images showing the microstructure of T6-treated $\mathrm{Mg}-12 \mathrm{Ag}-0.1 \mathrm{Ca}$ alloy sheet along (a) [0001 $]_{\mathrm{a}}$ zone axis and (b) $[10 \overline{1} 0]_{\mathrm{a}}$ zone axis.

Figure 9a shows the XRD pattern obtained from the T6-treated Mg-12Ag-0.1Ca alloy sheet. For the purpose of comparison, the XRD pattern obtained from the T4-treated sheet is given in Figure $9 \mathrm{~b}$. As can be seen that the T4-treated sample mainly consists of a-Mg phase. After the T6-treatment, new peaks are clearly observable, and they are confirmed to be generated mainly by $\mathrm{MgAg}_{4}$ phase. Therefore, the improvement in the tensile yield strength is associated with the formation of $\mathrm{AgMg}_{4}$ precipitates by the T6 treatment.

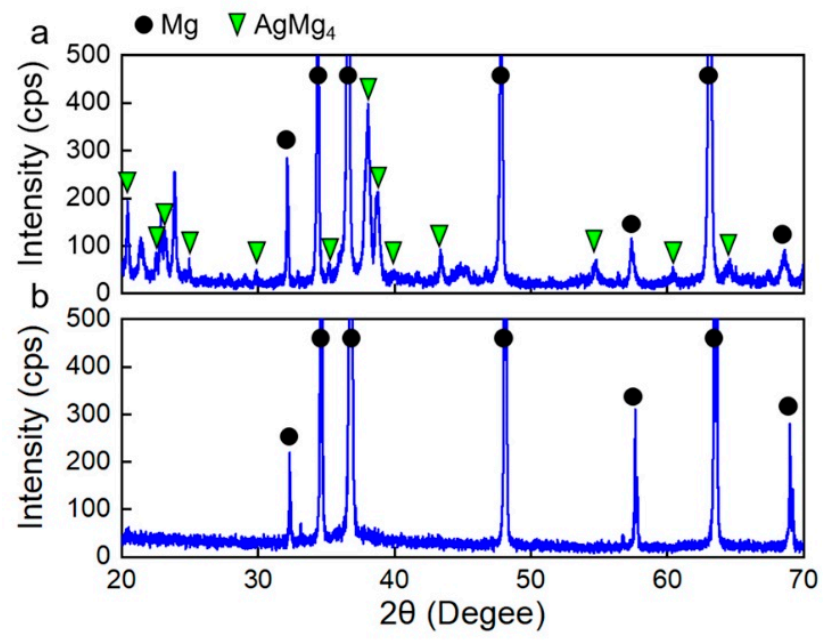

Figure 9. (a) X-ray diffraction (XRD) pattern obtained from T6-treated 12Ag containing alloy sheet. For the purpose of comparison, XRD pattern obtained from T4-treated 12Ag containing alloy sheet is given in (b).

To know whether there is an orientation relationship (OR) between $\mathrm{AgMg}_{4}$ phase and $\mathrm{a}-\mathrm{Mg}$ matrix, further microstructure analysis was carried out on the T6-treated 12Ag containing alloy sheet. Figure 10a shows the HAADF-STEM image with the zone axis of [0001 $]_{a}$, and Figure $10 \mathrm{~b}$ shows the high resolution (HR) HAADF-STEM image that is enlarged from the rectangular region in Figure 10a. Figure 10c,d are the fast Fourier transform (FFT) patterns generated from the left-hand region and right-hand region of Figure 10b, respectively. Analysis of these patterns reveals that left-hand region is 
the $\alpha-\mathrm{Mg}$ matrix with the zone axis of $[0001]_{\mathrm{a}}$ and the right-hand region is the $\mathrm{AgMg}_{4}$ phase with the zone axis of [0001] AgMg4. By further analyzing the FFT patterns, the OR between the $\alpha-\mathrm{Mg}$ matrix and $\mathrm{AgMg}_{4}$ is confirmed to be $(0001)_{\mathrm{a}}\left\|(0001)_{\mathrm{AgMg}_{4}},[\overline{2} 110]_{\mathrm{a}}\right\|\left[{ }_{10} \overline{10}\right]_{\mathrm{AgMg} 4}$.
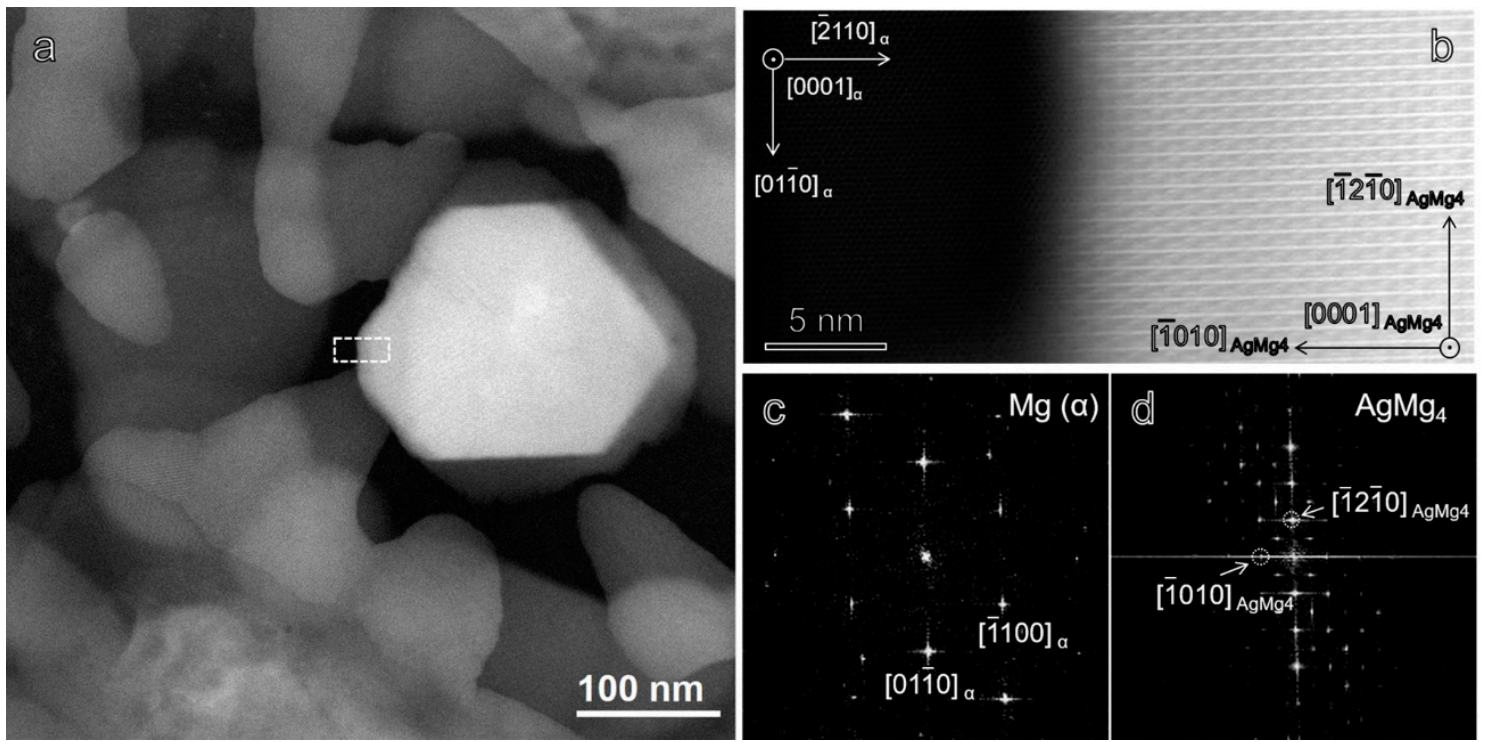

Figure 10. (a) HAADF-STEM image recorded along the [0001 $]_{a}$ direction. (b) Enlargement of the marked region in (a). FFT patterns generated from (c) $\alpha$-Mg matrix and (d) $\mathrm{AgMg}_{4}$ phase showing their orientation relationship.

\section{Discussion}

In the present study, we have successfully developed a new type of precipitation-hardenable $\mathrm{Mg}-\mathrm{Ag}-\mathrm{Ca}$ sheet alloys. In the T4-treated condition, the 1.5Ag containing alloy sheet shows a large average grain size of $\sim 277 \mu \mathrm{m}$. In addition, abnormal grain growth occurs, as shown in Figure 5a. From our previous study, this alloy sheet subjected to $350^{\circ} \mathrm{C}$ annealing for $1.5 \mathrm{~h}$ exhibits a homogeneous microstructure that consists of equiaxed grains with an average grain size of $20 \mu \mathrm{m}$ [14], indicating abnormal grain growth is likely to occur at higher temperatures. In the case of the pure $\mathrm{Mg}$ and Mg alloy AZ31 (Mg-3Al-1Zn-0.3Mn in wt.\%) [25,26], it seems that abnormal grain growth occurs at intermediate temperatures rather than higher temperatures, which is different from the trend observed in the present study. For example, abnormal grain growth occurs at an annealing temperature of $220{ }^{\circ} \mathrm{C}$, while normal grain grow occurs at a higher temperature of $350{ }^{\circ} \mathrm{C}$ [25]. It was reported that recrystallized grains with the $<11 \overline{2} 0>\|$ RD orientation grow preferentially at the expense of deformed matrix grains close to the $<10 \overline{1} 0>\|$ RD orientation and neighboring recrystallized small grains, thereby evolving to abnormally large sizes in pure Mg and AZ31 alloy [27,28]. Figure 11 shows EBSD IPF maps and corresponding IPFs from abnormally coarse grains $(>100 \mu \mathrm{m})$ and normal-size grains $(\leq 100 \mu \mathrm{m})$ in the T4-treated $1.5 \mathrm{Ag}$ containing alloy sheet. As can be seen, the normal-size grains have mainly the $<1 \overline{12} 0>\|$ RD orientation while the abnormally coarse grains do not have such orientation. These results suggest that the mechanism responsible for abnormal grain growth in $\mathrm{Mg}-\mathrm{Ag}-\mathrm{Ca}$ alloys is likely to be different from that in pure Mg and AZ31 alloy. It is to be noted that a homogeneous microstructure is developed in the 12Ag containing alloy sheet, Figure 5c. Ag and Ca atoms are demonstrated to be enriched in grain boundaries of the T4-treated condition, as shown in Figure 7. It is believed that solute segregation to grain boundaries occurs in the 1.5Ag containing alloy as well. However, the degree of solute segregation should be much lower than that in the $12 \mathrm{Ag}$ containing alloy. It is thus hypothesized that the segregated solute atoms effectively reduce grain boundary mobility via solute drag effects, thereby leading to a homogeneous microstructure. This hypothesis is supported by the homogeneous microstructure developed in the $1.5 \mathrm{Ag}$ containing alloy sheet after $350{ }^{\circ} \mathrm{C}$ annealing for $1.5 \mathrm{~h}$. Based on 
the PANDAT calculation, the solid solubility of $\mathrm{Ag}$ in $\mathrm{Mg}$ is substantially decreased from $10 \mathrm{wt}$. $\%$ to 1.42 wt.\% with decreasing the temperature from $450{ }^{\circ} \mathrm{C}$ to $350^{\circ} \mathrm{C}$, as shown in Figure 12 . Considering less $\mathrm{Ag}$ atoms will be dissolved into a- $\mathrm{Mg}$ matrix and more $\mathrm{Ag}$ atoms segregate to grain boundaries at $350{ }^{\circ} \mathrm{C}$, the degree of solute segregation is expected to be much stronger than that at $450{ }^{\circ} \mathrm{C}$. As such grain boundaries are difficult to break away from the solute drag atmosphere and remain pinned in the $1.5 \mathrm{Ag}$ containing alloy after $350{ }^{\circ} \mathrm{C}$ annealing.

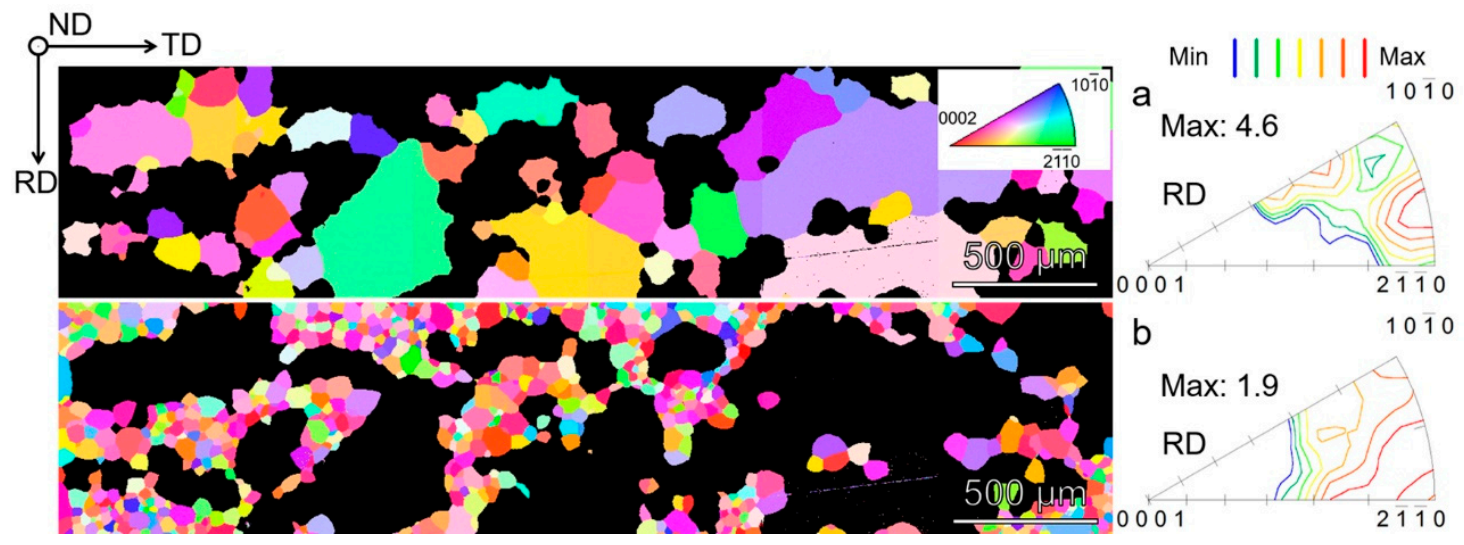

Figure 11. EBSD IPF maps and corresponding inverse pole figures showing textures of (a) abnormally coarse grains and $(\mathbf{b})$ normal-size grains in the T4-treated $\mathrm{Mg}-1.5 \mathrm{Ag}-0.1 \mathrm{Ca}$ alloy sheet.

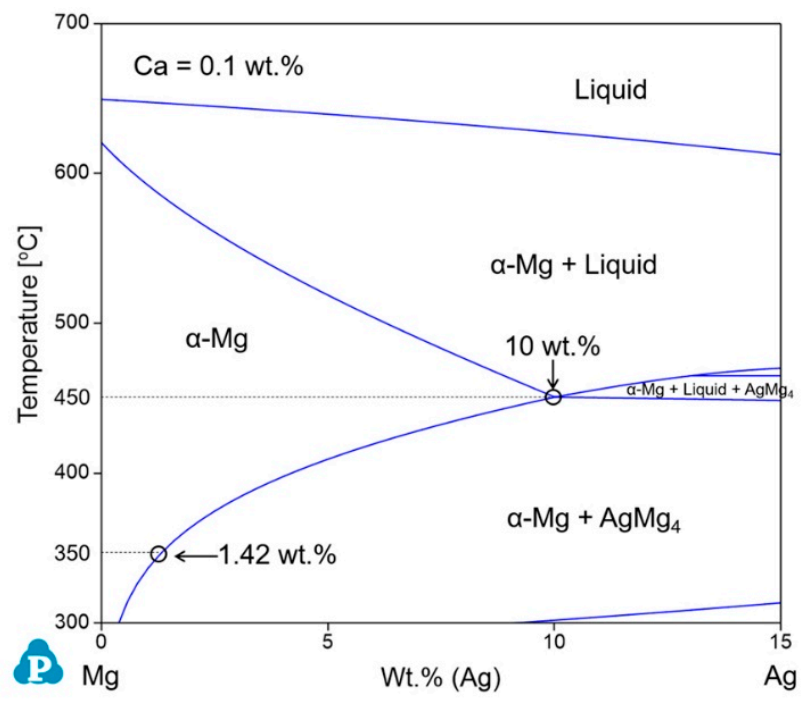

Figure 12. Calculated Mg-Ag phase diagram using the PANDAT software, in which the Ca content is fixed as $0.1 \mathrm{wt} . \%$.

In the T4-treated condition, the TYS strength is substantially enhanced by increasing the Ag content from $1.5 \mathrm{wt}$. \% to $12 \mathrm{wt} \%$. The $12 \mathrm{Ag}$ containing alloy sheet shows a homogeneous microstructure with an average grain size of $\sim 74 \mu \mathrm{m}$. Thus, the increased TYS can be mainly ascribed to the refinement in the microstructure and solid solution strengthening effect. Nonetheless, the average grain size of the $\mathrm{Mg}-12 \mathrm{Ag}-0.1 \mathrm{Ca}$ alloy is still much coarser than the those developed in precipitation-hardenable $\mathrm{Mg}-\mathrm{Zn}-\mathrm{Ca}-\mathrm{Zr}$ and Mg-Al-Ca-Mn(-Zn) alloys $(<10 \mu \mathrm{m})[8,11,12,29]$. This is because fine second phase particles that can effectively retard the growth of recrystallized grains are not present in the $12 \mathrm{Ag}$ containing alloy. Addition of small amounts of $\mathrm{Al}$ and $\mathrm{Mn}$ or $\mathrm{Zn}$ and $\mathrm{Zr}$ to in the $\mathrm{Mg}-12 \mathrm{Ag}-0.1 \mathrm{Ca}$ alloy might be promising to reduce the average grain size in the T4-condition by forming a densely distributed nano-scale $\mathrm{Al}_{8} \mathrm{Mn}_{5}$ or $\mathrm{Zn}_{2} \mathrm{Zr}_{3}$ particles [30,31]. On the other hand, all alloys exhibit a higher 
TYS along the RD than along the TD due to the formation of the TD-split texture. Such a texture is beneficial for $(0001)<11 \overline{2} 0>$ basal slip and $\{10 \overline{1} 2\}$ tensile twin to accommodate the plastic deformation along the TD than the RD as their Schmid factor values are higher along the TD than the RD [32-36].

The TYS of the 12Ag containing alloy sheet is $193 \mathrm{MPa}, 130 \mathrm{MPa}$ and $117 \mathrm{MPa}$ along the RD, $45^{\circ}$ and TD, respectively. The T6 treatment further increases the TYS to $236 \mathrm{MPa}, 163 \mathrm{MPa}$ and $143 \mathrm{MPa}$. The strength enhancement by the T6-treatment is rather low compared to other alloys such as $\mathrm{Mg}-\mathrm{Gd}$ [37], $\mathrm{Mg}-\mathrm{Zn}$ [38] and $\mathrm{Mg}-\mathrm{Sn}$ [39] based wrought alloys. Microstructure characterization reveals that non-basal $\mathrm{AgMg}_{4}$ precipitates are formed in the T6-treated sample and their coarse microstructure is the main reason for the inferior age hardenability. There are several ways to refine the size of precipitates by increasing the number density of nucleation sites in early stage of aging: (i) deformation prior to aging treatment [40,41]; (ii) double aging consist of low temperature aging followed by high temperature aging [42-44]; and (iii) addition of trace amounts of elements [21,45,46]. Further optimization of the alloy composition incorporated with the modification of thermomechanical process is therefore expected to improve the age-hardening response and accelerate aging kinetics of Mg-Ag-Ca alloys.

\section{Conclusions}

Precipitation-hardenable wrought $\mathrm{Mg}$ alloy has been successfully developed based on the $\mathrm{Mg}-\mathrm{Ag}-\mathrm{Ca}$ system. In a T4-treated condition, the TYS of Mg-1.5Ag-0.1Ca alloy sheet is only $85 \mathrm{MPa}$, $57 \mathrm{MPa}$ and $47 \mathrm{MPa}$ along the $\mathrm{RD}, 45^{\circ}$ and TD, respectively. With increase in the Ag content to 12 wt. $\%$, the TYS is increased to $193 \mathrm{MPa}, 130 \mathrm{MPa}$ and $117 \mathrm{MPa}$ along the RD, $45^{\circ}$ and TD, which can be mainly ascribed to a refined microstructure and solid solution strengthening effect. Artificial aging at $170{ }^{\circ} \mathrm{C}$ for $336 \mathrm{~h}$ (T6) further increases the TYS of Mg-12Ag-0.1Ca alloy sheet to $236 \mathrm{MPa}, 163 \mathrm{MPa}$ and $143 \mathrm{MPa}$ along the $\mathrm{RD}, 45^{\circ}$ and $\mathrm{TD}$. $\mathrm{AgMg}_{4}$ precipitates lying on the $\{11 \overline{2} 0\}_{a}$ and pyramidal planes are responsible for the strength improvement.

Author Contributions: Conceptualization, M.B.; methodology, M.B.; validation, X.H. and Y.C.; investigation, M.B. and X.H.; writing—original draft preparation, M.B.; writing-review and editing, X.H. and Y.C.; project administration, Y.C.; funding acquisition, M.B. and X.H. All authors have read and agreed to the published version of the manuscript.

Funding: This research was funded by JSPS KAKENHI, grant numbers JP20K15067 and JP18K04787.

Conflicts of Interest: The authors declare no conflict of interest. The funders had no role in the design of the study; in the collection, analyses, or interpretation of data; in the writing of the manuscript, or in the decision to publish the results.

\section{References}

1. Hirsch, J.; Al-Samman, T. Superior light metals by texture engineering: Optimized aluminum and magnesium alloys for automotive applications. Acta Mater. 2013, 61, 818-843. [CrossRef]

2. Joost, W.J.; Krajewski, P.E. Towards magnesium alloys for high-volume automotive applications. Scr. Mater. 2017, 128, 107-112. [CrossRef]

3. Letzig, D.; Bohlen, J.; Kurz, G.; Victoria-Hernandez, J.; Hoppe, R.; Yi, S. Development of magnesium sheets. In Magnesium Technology 2018; The Minerals, Metals and Materials Series; Springer International Publishing: Berlin/Heidelberg, Germany, 2018; Volume F7, pp. 355-360.

4. Kim, N.J. Magnesium sheet alloys: Viable alternatives to steels? Mater. Sci. Technol. 2014, 30, 1925-1928. [CrossRef]

5. Nie, J.-F. Precipitation and hardening in magnesium alloys. Metall. Mater. Trans. A 2012, 43, 3891-3939. [CrossRef]

6. Hono, K.; Mendis, C.L.; Sasaki, T.T.; Oh-ishi, K. Towards the development of heat-treatable high-strength wrought Mg alloys. Scr. Mater. 2010, 63, 710-715. [CrossRef]

7. Homma, T.; Kunito, N.; Kamado, S. Fabrication of extraordinary high-strength magnesium alloy by hot extrusion. Scr. Mater. 2009, 61, 644-647. [CrossRef] 
8. Mendis, C.L.; Bae, J.H.; Kim, N.J.; Hono, K. Microstructures and tensile properties of a twin roll cast and heat-treated Mg-2.4Zn-0.1Ag-0.1Ca-0.1Zr alloy. Scr. Mater. 2011, 64, 335-338. [CrossRef]

9. Nakata, T.; Mezaki, T.; Ajima, R.; Xu, C.; Oh-Ishi, K.; Shimizu, K.; Hanaki, S.; Sasaki, T.T.; Hono, K.; Kamado, S. High-speed extrusion of heat-treatable Mg-Al-Ca-Mn dilute alloy. Scr. Mater. 2015, 101, 28-31. [CrossRef]

10. Nakata, T.; Xu, C.; Ajima, R.; Shimizu, K.; Hanaki, S.; Sasaki, T.T.; Ma, L.; Hono, K.; Kamado, S. Strong and ductile age-hardening Mg-Al-Ca-Mn alloy that can be extruded as fast as aluminum alloys. Acta Mater. 2017, 130, 261-270. [CrossRef]

11. Bian, M.Z.; Sasaki, T.T.; Suh, B.C.; Nakata, T.; Kamado, S.; Hono, K. A heat-treatable Mg-Al-Ca-Mn-Zn sheet alloy with good room temperature formability. Scr. Mater. 2017, 138, 151-155. [CrossRef]

12. Li, Z.H.; Sasaki, T.T.; Bian, M.Z.; Nakata, T.; Yoshida, Y.; Kawabe, N.; Kamado, S.; Hono, K. Role of Zn on the room temperature formability and strength in $\mathrm{Mg}-\mathrm{Al}-\mathrm{Ca}-\mathrm{Mn}$ sheet alloys. J. Alloys Compd. 2020, 847, 156347. [CrossRef]

13. Bian, M.Z.; Sasaki, T.T.; Nakata, T.; Yoshida, Y.; Kawabe, N.; Kamado, S.; Hono, K. Bake-hardenable $\mathrm{Mg}-\mathrm{Al}-\mathrm{Zn}-\mathrm{Mn}-\mathrm{Ca}$ sheet alloy processed by twin-roll casting. Acta Mater. 2018, 158, 278-288. [CrossRef]

14. Bian, M.; Huang, X.; Chino, Y. A room temperature formable magnesium-silver-calcium sheet alloy with high ductility. Mater. Sci. Eng. A 2020, 774, 138923. [CrossRef]

15. Bian, M.; Huang, X.; Chino, Y. A combined experimental and numerical study on room temperature formable magnesium-silver-calcium alloys. J. Alloys Compd. 2020, 155017. [CrossRef]

16. Bian, M.; Huang, X.; Chino, Y. Improving flame resistance and mechanical properties of magnesium-silver-calcium sheet alloys by optimization of calcium content. J. Alloys Compd. 2020, 837, 155551. [CrossRef]

17. Nayeb-Hashemi, A.A.; Clark, J.B. Phase Diagrams of Binary Magnesium Alloys; ASM International: Metals Park, OH, USA, 1988; ISBN 9780871703286.

18. Payne, R.J.M.; Bailey, N. Improvement of the age hardening properties of magnesium-rare-earth alloys by addition of silver. J. Inst. Met. 1960, 88, 417-427.

19. Gao, X.; Nie, J.F. Enhanced precipitation-hardening in Mg-Gd alloys containing Ag and Zn. Scr. Mater. 2008, 58, 619-622. [CrossRef]

20. Zhu, Y.M.; Morton, A.J.; Nie, J.F. Improvement in the age-hardening response of Mg-Y-Zn alloys by Ag additions. Scr. Mater. 2008, 58, 525-528. [CrossRef]

21. Mendis, C.L.; Oh-ishi, K.; Hono, K. Enhanced age hardening in a Mg-2.4 at.\% Zn alloy by trace additions of Ag and Ca. Scr. Mater. 2007, 57, 485-488. [CrossRef]

22. Cao, W.; Chen, S.L.; Zhang, F.; Wu, K.; Yang, Y.; Chang, Y.A.; Schmid-Fetzer, R.; Oates, W.A. PANDAT software with PanEngine, PanOptimizer and PanPrecipitation for multi-component phase diagram calculation and materials property simulation. Calphad 2009, 33, 328-342. [CrossRef]

23. Pennycook, S.J.; Jesson, D.E. High-resolution Z-contrast imaging of crystals. Ultramicroscopy 1991, 37, 14-38. [CrossRef]

24. Pennycook, S.J.; Jesson, D.E. Atomic resolution Z-contrast imaging of interfaces. Acta Metall. Mater. 1992, 40, S149-S159. [CrossRef]

25. Pei, R.; Korte-Kerzel, S.; Al-Samman, T. Normal and abnormal grain growth in magnesium: Experimental observations and simulations. J. Mater. Sci. Technol. 2020, 50, 257-270. [CrossRef]

26. Bhattacharyya, J.J.; Agnew, S.R.; Muralidharan, G. Texture enhancement during grain growth of magnesium alloy AZ31B. Acta Mater. 2015, 86, 80-94. [CrossRef]

27. Gottstein, G.; Alsamman, T. Texture development in pure Mg and Mg alloy AZ31. Mater. Sci. Forum 2005, 195-197, 623-632. [CrossRef]

28. Steiner, M.A.; Bhattacharyya, J.J.; Agnew, S.R. The origin and enhancement of $\{0001\}\langle 11-20\rangle$ texture during heat treatment of rolled AZ31B magnesium alloys. Acta Mater. 2015, 95, 443-455. [CrossRef]

29. Li, Z.H.; Sasaki, T.T.; Shiroyama, T.; Miura, A.; Uchida, K.; Hono, K. Simultaneous achievement of high thermal conductivity, high strength and formability in Mg-Zn-Ca-Zr sheet alloy. Mater. Res. Lett. 2020, 8, 335-340. [CrossRef]

30. Trang, T.T.T.; Zhang, J.H.; Kim, J.H.; Zargaran, A.; Hwang, J.H.; Suh, B.-C.; Kim, N.J. Designing a magnesium alloy with high strength and high formability. Nat. Commun. 2018, 9, 2522. [CrossRef]

31. Gao, X.; Muddle, B.C.; Nie, J.F. Transmission electron microscopy of Zr-Zn precipitate rods in magnesium alloys containing Zr and Zn. Philos. Mag. Lett. 2009, 89, 33-43. [CrossRef] 
32. Bohlen, J.; Cano, G.; Drozdenko, D.; Dobron, P.; Kainer, K.; Gall, S.; Müller, S.; Letzig, D. Processing Effects on the Formability of Magnesium Alloy Sheets. Metals 2018, 8, 147. [CrossRef]

33. Yan, H.; Xu, S.W.; Chen, R.S.; Kamado, S.; Honma, T.; Han, E.H. Activation of $\{10-12\}$ twinning and slip in high ductile $\mathrm{Mg}-2.0 \mathrm{Zn}-0.8 \mathrm{Gd}$ rolled sheet with non-basal texture during tensile deformation at room temperature. J. Alloys Compd. 2013, 566, 98-107. [CrossRef]

34. Chino, Y.; Sassa, K.; Mabuchi, M. Texture and stretch formability of a rolled Mg-Zn alloy containing dilute content of Y. Mater. Sci. Eng. A 2009, 513-514, 394-400. [CrossRef]

35. Chino, Y.; Huang, X.; Suzuki, K.; Sassa, K.; Mabuchi, M. Influence of Zn concentration on stretch formability at room temperature of Mg-Zn-Ce alloy. Mater. Sci. Eng. A 2010, 528, 566-572. [CrossRef]

36. Bohlen, J.; Nürnberg, M.R.; Senn, J.W.; Letzig, D.; Agnew, S.R. The texture and anisotropy of magnesium-zinc-rare earth alloy sheets. Acta Mater. 2007, 55, 2101-2112. [CrossRef]

37. He, S.M.; Zeng, X.Q.; Peng, L.M.; Gao, X.; Nie, J.F.; Ding, W.J. Microstructure and strengthening mechanism of high strength Mg-10Gd-2Y-0.5Zr alloy. J. Alloys Compd. 2007, 427, 316-323. [CrossRef]

38. Mendis, C.L.; Oh-ishi, K.; Kawamura, Y.; Honma, T.; Kamado, S.; Hono, K. Precipitation-hardenable Mg-2.4Zn-0.1Ag-0.1Ca-0.16Zr (at.\%) wrought magnesium alloy. Acta Mater. 2009, 57, 749-760. [CrossRef]

39. Sasaki, T.T.; Elsayed, F.R.; Nakata, T.; Ohkubo, T.; Kamado, S.; Hono, K. Strong and ductile heat-treatable Mg-Sn-Zn-Al wrought alloys. Acta Mater. 2015, 99, 176-186. [CrossRef]

40. The effect of cold work on precipitation in alloy WE54. In Proceedings of the Magnesium Alloys and Their Applications, Wolfsburg, Germany, 28-30 April 1998; pp. 329-334.

41. Shi, G.L.; Zhang, D.F.; Zhang, H.J.; Zhao, X.B.; Qi, F.G.; Zhang, K. Influence of pre-deformation on age-hardening response and mechanical properties of extruded $\mathrm{Mg}-6 \% \mathrm{Zn}-1 \% \mathrm{Mn}$ alloy. Trans. Nonferrous Met. Soc. China 2013, 23, 586-592. [CrossRef]

42. Oh-ishi, K.; Hono, K.; Shin, K.S. Effect of pre-aging and Al addition on age-hardening and microstructure in Mg-6 wt\% Zn alloys. Mater. Sci. Eng. A 2008, 496, 425-433. [CrossRef]

43. Sasaki, T.T.; Oh-ishi, K.; Ohkubo, T.; Hono, K. Effect of double aging and microalloying on the age hardening behavior of a Mg-Sn-Zn alloy. Mater. Sci. Eng. A 2011, 530, 1-8. [CrossRef]

44. Mendis, C.L.; Oh-ishi, K.; Ohkubo, T.; Shin, K.S.; Hono, K. Microstructures and mechanical properties of extruded and heat treated Mg-6Zn-1Si-0.5Mn alloys. Mater. Sci. Eng. A 2012, 553, 1-9. [CrossRef]

45. Mendis, C.L.; Bettles, C.J.; Gibson, M.A.; Hutchinson, C.R. An enhanced age hardening response in Mg-Sn based alloys containing Zn. Mater. Sci. Eng. A 2006, 435-436, 163-171. [CrossRef]

46. Sasaki, T.T.; Oh-ishi, K.; Ohkubo, T.; Hono, K. Enhanced age hardening response by the addition of Zn in Mg-Sn alloys. Scr. Mater. 2006, 55, 251-254. [CrossRef]

Publisher's Note: MDPI stays neutral with regard to jurisdictional claims in published maps and institutional affiliations.

(C) 2020 by the authors. Licensee MDPI, Basel, Switzerland. This article is an open access article distributed under the terms and conditions of the Creative Commons Attribution (CC BY) license (http://creativecommons.org/licenses/by/4.0/). 